Syntax Literate: Jurnal Ilmiah Indonesia p-ISSN: 2541-0849

e-ISSN: 2548-1398

Vol. 5, No. 9, September 2020

\title{
ANALISIS PEMANFAATAN TEKNOLOGI DALAM PENGELOLAAN DOKUMEN WARGA BINAAN PEMASYARAKATAN
}

\section{Rayinda Estri Maula}

Politeknik Ilmu Pemasyarakatan Depok Jawa Barat, Indonesia

Email: rayinda292@gmail.com

\section{Abstract}

This research aims to analyze the utilization of technology in the framework of the implementation of confidential documents such as the data of prison community. The research is backed by the abundance of data on the target citizens who have to be processed and archived structured from the period of detention in the stage of investigation, prosecution and up to the fall of the criminal ruling, as well as the management of the data of the target citizens To be processed in order to grant the rights of the target citizen in the construction period in correctional institution. Information technology is used to assist criminal calculations and the management of digital data archives, thus creating accountable, precise and transparent public information. Based on the problems that arise from current issues, we use the theory and review by literature on management of information technology-based data. The study includes understanding, objectives, and utilization indicators that can be adopted by the system management and archisiation of community-building people. Proposed hypothesis: Information technology affects data management and conversion by digitizing methods so that data can be integrated. From the results of this research, there is a conclusion that information technology presents a useful element for the management and conversion of the Community data workers and the influence on the integrated work pattern.

Keywords: information technology; document management; correctional

Abstrak

Penelitian ini bertujuan menganalisa pemanfaatan teknologi dalam rangka pelaksanaan pengelolaan dokumen yang bersifat rahasia seperti data-data warga binaan pemasyarakatan. Adapun penelitian ini dilatarbelakangi oleh banyaknya data warga binaan yang harus diolah dan diarsipkan secara terstruktur mulai dari masa penahanan ditiap tahap penyidikan, penuntutan dan hingga jatuhnya putusan pidana, serta pengelolaan data warga binaan pemasyarakatan yang harus diolah guna pemberian hak-hak warga binaan dalam masa pembinaan di dalam Lembaga Pemasyarakatan. Teknologi informasi digunakan untuk membantu perhitungan pidana dan pengelolaan kearsipan data secara digital, sehingga menciptakan informasi publik yang akuntabel, tepat dan transparan. Berdasarkan permasalahan yang muncul dari isu aktual saat ini, kami menggunakan teori dan kajian literatur mengenai manajemen pengelolaan data berbasis teknologi informasi. Kajian tersebut meliputi pengertian, tujuan, serta indikator pemanfaatan yang dapat diadopsi oleh sistem pengelolaan dan pengarsiapan data warga binaan 
pemasyarakatan. Hipotesis yang diajukan: Teknologi Informasi berpengaruh pada pengelolaan data dan kearsiapan dengan metode digitalisasi sehingga data dapat terintegrasi. Dari hasil penelitian ini terdapat kesimpulan bahwa teknologi informasi menghadirkan bergabagai unsur yang bermanfaat bagi pengelolaan dan kearsiapan data warga binaan pemasyarakatan serta berpengaruh pada pola kerja yang terintegrasi.

Kata kunci: Pemasyarakatan; Pengelolaan Dokumen; Teknologi Informasi.

\section{Pendahuluan}

Pada dasarnya setiap organisasi ataupun Lembaga Pemerintahan akan selalu berusaha meningkatkan pelayanan dan menunjukan eksistensinya yang melekat dengan perkembangan teknologi dan kebutuhan masyarakat. Hadirnya kemajuan generasi teknologi yang kompetitif memerlukan penanganan dan konsentrasi khusus terhadap sumber daya manusia sebagai pengelola atas penggunaan metode digitalisasi dalam pengelolaan data menjadi informasi yang terintegrasi. Era digitalisasi dengan kemajuan teknologinya mempengaruhi Lembaga Pemerintah untuk melakukan pemanfaatan teknologi yang ada untuk membantu mempermudah pengelolaan data hingga segala jenis pengurusan kearsipan yang dibutuhkan.

Dengan adanya penerapan sistem informasi dalam pelaksanaan tugas dan fungsi pemasyarakatan, dibutuhkan peran petugas pemasyarakatan yang menguasai perkembangan teknologi dan tentu saja mempunyai keahlian keterampilan pengolahan informasi berbasis komputer. Arus pertumbuhan kuantitas warga binaan pemasyarakatan setiap tahunnya, menimbulkan permasalahan yang harus sesegera mungkin diselesaikan dengan percepatan pelayanan, pembinaan dan pemberian program pembinaan yang sesuai, cepat dan tepat sehingga mempunyai nilai efektif dan efisien tanpa mengesampingkan tugas dan fungsi-fungsi Pemasyarakatan.

Dalam beberapa tahun terakhir, Pemasyarakatan syarat dengan pemberitaan miring yang sangat merugikan yang dilakukan oleh oknum petugas pemasyarakatan baik pelaksana tugas maupun pejabat struktural. Adapun beberapa yang dapat di ingat adalah penyalahgunaan wewenang dan prosedur pelaksanaan pengawalan Setya Novanto sehingga memicu pemberitaan 'Napi Koruptor Plesir', terjadinya salah prosedur dalam pelaksanaan pengeluaran narapidana, ketidaksesuaian pelaksanaan pemberian hak narapidana seperti pemberian remisi dan program pembinaan lain yang syarat dengan isu 'jual beli', hingga tersebar kabar bahwa Pemasyarakatan tidak lagi berjalan sesuai dengan tugas dan fungsi dikarenakan banyak penyelewengan dan perkara yang ada dalam tubuh pemasyarakatan itu sendiri.

Permasaahan seperti ini sudah terjadi sejak lama, sehingga membuat Direktorat Jenderal Pemasyarakatan mulai mengaplikasikan teknologi dalam Layanan Informasi publik. Sebagaimana telah dijelaskan dalam Keputusan Direktur Jenderal Pemasyarakatan Nomor PAS1.14.OT.02.02 Tanggal 15 Juli 2014 tentang Standar Pelayanan Pemasyarakatan sebagai upaya terciptanya pelayan prima terhadap penerima layanan khususnya bagi Warga Binaan Pemasyarakatan, masyarakat, dan stakeholder 
sekaligus penerapan Good Governance yang mengedepankan optimalisasi pemberian layanan, Direktorat Jenderal Pemasyarakatan menetapkan mengimplementasikan perkembangan teknologi sebagai salah satu cara dalam mewujudkan layanan publik yang transparan, efektif dan efisien, akuntabel, dan dapat dipertanggungjawabkan, serta untuk menghasilkan layanan informasi yang berkualitas.

Dalam penelitian ini permaslahan yang akan diteliti adalah sejauh mana pemanfaatan teknologi dalam pengelolaan dokumen warga binaan pemasyarakatan dalam mewujudkan keterbukaan informasi.

Penelitian ini bertujuan untuk menganalisa pelaksanaan penerapan teknologi informasi dalam rangka pengelolaan data warga binaan pemasyarakatan. Dan diharapkan melalui penelitian ini dapat memberikan informasi dan manfaat yang berguna baik dalam kepentingan akademik maupun bagi instansi terkait serta masyarakat yang membutuhkan.

\section{Metode Penelitian}

Dalam kegiatan menjawab permasalahan penelitian, peneliti menggunakan beberapa langkah yang bersifat ilmiah yang terdiri dari kajian kepustakaan, penelitian deskriptif dan pendekatan kualitatif.

Dalam perancangan penelitian, penulis melakukan studi analisis berdasarkan beberapa artikel tentang pelaksanaan pengelolaan data secara digital. Penulis mempelajari penelitian tentang penerapan layanan teknologi informasi dalam penyimpanan dan pengelolaan benda sitaan dan barang rampasan negara di rumah penyimpanan benda sitaan dan barang rampasan negara kelas I Bandung.

Penelitian Deskriptif disebut juga dengan penelitian observasi taksonomik, menurut Ernayanti Lubis, penelitian ini dimaksudkan untuk mengeksplorasi mengenai suatu fenomena atau kenyataan social dengan mendeskripsikan beberapa variabel yang berkenaan dengan berkenaan dengan masalah dan unit yang diteliti jenis penelitian ini tidak mempersoalkan jaringan hubungan variable, sehingga tidak melakukan pengujian hipotesis (Lubis, 2014).

Dalam hal ini penulis menggunakan juga metode pendekatan kualitatif fenomenologi. Menurut Kuswarno, Fenomenologi adalah fakta yang didasari dan masuk ke pemahaman manusia, merefleksikan pengalaman langsung manusia, sejauh pengalaman itu berhubungan dengan suatu objek yang diteliti (Violetta K, n.d.).

\section{Hasil dan Pembahasan}

1. Sarana dan prasarana

Sarana dan prasarana menjadi alat utama dalam pelaksanaan pengelolaan data. Adanya keterbatasan sarana dalam melakukan kegiatan pengelolaan data warga binaan pemasyarakatan seperti peng-roll-an, registrasi dan hingga pengarsipan berkas tidak berjalan dengan baik sesuai dengan kaidah kearsipan yaitu menghindari kemungkinan terjadinya pelanggaran hukum terhadap kearsipan seperti: a. Penipuan computer: perusakan, penipuan dan pencurian data. b. Privasi (perlindungan data) 
dan penyebaran informasi. c. Tanpa hak memasuki system computer/melakukan upaya pencurian data. d. Perlindungan hak cipta. e. Kerahasiaan data (Laksmi, 2008).

Dalam masa observasi, penulis menemukan permasalahan yang terjadi dalam penggunaan sarana dan prasarana, antara lain: a. Penggunaan sarana dan prasarana tidak sesuai dengan peruntukan yang semestinya. Banyak intervensi dari bidang kerja lain yang juga turut menggunakan sarana dan prasarana yang peruntukannya telah di tetapkan untuk pengelolaan data. Biasanya sarana dan prasarana yang demikian adalah computer, scanner, dan ruangan. b. Pelaksanaan perawatan berkala atau maintenance sarana dan prasarana yang tidak berjalan, atau hanya sebagai formalitas. c. Tidak tersedianya kartu control kelayakan sarana dan prasarana. d. Sarana dan prasarana sering digunakan untuk kepentingan pribadi oleh pelaksana atau pengelola data warga binaan. Seperti penggunaan akses internet atau perangkat internet lainnya untuk keperluan diluar dinas. Diungkapkan juga bahwa piranti elektronik internet juga mempunyai peranan yang penting dalam pembangunan informasi berbasis teknologi (Suwardi, 2014). Selain itu teknologi informasi dan komunikasi digunakan sebagai media untuk meneruskan kegiatan yang tidak dapat dilakukan secara tatap muka (Komalasari, 2016).

2. Sumber daya manusia

Sumber daya manusia merupakan Angkatan kerja atau penduduk yang berusia 15 tahun keatas yang dapat dipekerjakan pada satu atau lebih bidang pekerjaan tertentu dalam kegiatan produksi (Bangun, 2017). Pada pembahasan ini sumber daya manusia diasumsikan sebagai petugas pemasyarakatan atau seseorang yang melakukan pengelolaan data warga binaan pemasyarakatan. Dalam pengelolaan data warga binaan pemasyarakatan terdapat pembagian level pengelola data warga binaan pemasyarakatan yang dibagi menjadi Operator, Administrator dan Supervisor (Informasi et al., 2013). Sesuai dengan aturan pada Standar dan Modul Pelayanan Berbasis IT, pelaksanaan pengelolaan data dilaksanakan berdasarkan asas kepatuhan aturan dasar prnggunaan Sistem Database Pemasyarakatan sesuai dengan izin yang dikeluarkan oleh Direktorat Infomasi dan Komunikasi Direktorat Jenderal Pemasyarakatan (Informasi et al., 2013). Dalam pemberian bekal bagi sumber daya manusia di lingkungan Pemasyarakatan yang mendorong Rencana Aksi Nasional Kementerian Hukum dan Hak Asasi Manusia Tahun 2013, Direktorat Jenderal Pemasyarakatan telah melakukan bimbingan teknis bagi Asministrator SDP pada seluruh Lapas/Rutan (Direktorat Informasi dan Komunikasi Direktorat Jenderal Pemasyarakatan, 2013).

3. Arus perkembangan teknologi

Dalam pemanfaatan peran teknologi seorang pemimpin dapat melibatkan orang lain dalam penyelesaian masalah bersama untuk keperluan pencapaian tujuan organisasi. Kehadiran teknologi komunikasi dan informasi dengan "segudang" kecanggihan dan kemudahan yang dibawanya mampu mengantar manusia ke sebuah tatanan yang memiliki kualitas dan standar hidup yang lebih baik (Ahmad, 2012). Hal ini tentu saja membutuhkan tingkat responsibilitas yang tinggi yang dikaitkan 
dengan usaha-usaha modernisasi dan dengan kemajuan teknologi sebagai media transformasinya. Sebagaimana diketahui bahwa penggunaan dari system informasi harus dikaitkan dengan usaha modernisasi, sedang proses modernisasi hanya dapat terjadi bila kemajuan telah dicapai dalam bidang ilmu pengetahuan dan teknologi (Rizan Machmud, 2013).

\section{Anggaran}

Ini adalah salah satu kendala yang menjadi penghalang dalam implementasi pemanfaatan teknologi dalam pengelolaan data. Dimana dalam tiap pelaksanaan pengadaan perawatan berkala (maintenance). Pada dasarnya (maintenance) atau perawatan ditujukan unutuk memperpanjang usia pemakaian alat dan juga meminimalisir pengeluaran uang untuk membeli alat baru yang bahkan membutuhkan dana yang tidak sedikit (Ekonomi, 2020). Disisi lain terdapat permasalahan bahwa anggaran akan bertambah bila sumber daya manusia yang ada tidak mampu melakukan pemanfaatan teknologi dengan baik, dan atau tidak mempunyai kompetensi di bidang teknologi terkait dengan pengelolaan data warga binaan pemasyarakatan.

5. Keamanan data

Data menurut Jogianto adalah kenyataan yang menggambarkan suatu kejadiankejadian dan kesatuan nyata (Febriyanti \& Hidayanto, 2012). Masalah keamanan data adalah aspek penting dalam pengelolaan data untuk menjamin keamanan data, informasi, pesan dan dokumen penting yang bersifat rahasia lainnya (Silalahi, 2014). Oleh karena itu diperlukan pengelolaan data secara teliti dan sistematis, akurat, mempunyai nilai efektif dan efisien untuk menghasilkan sebuah data informasi yang akurat dan terjamin keaslian datanya. Pentingnya pengelolaan data disebabkan oleh adanya aspek kepercayaan terhadap informasi publik, yaitu informasi yang disimpan, dikelola dan/atau dikirim/diterima oleh suatu badan publik yang berkaitan dengan penyelenggara dan penyelenggaraan negara dan/atau penyelenggara dan penyelenggaraan badan publik lainnya yang sesuai dengan undang-undang ini serta informasi lain yang berkaitan dengan kepentingan publik (Kristiyanto, 2016). Dengan keterbukaan informasi dan akurasi data dapat meningkatkan dan menjaga kepercayaan publik maupun warga binaan sendiri dikarenakan kepercayaan adalah opini atau pendapat yang seperti kepastian (Taylor, 2018). Menjamin keamanan data dan akurasi, Direktorat Jenderal Pemasyarakatan melakukan system konsolidasi untuk menjaga konsistensi pengelolaan data dan melakukan back up data secara nasional pada bid data dengan pengawasan implementasi konsolidasi di tingkat pusat adalah Direktorat Informasi dan Komunikasi, tingkat wilayah diberikan kepada Divisi Pemasyarakatan (Direktorat Informasi dan Komunikasi Direktorat Jenderal Pemasyarakatan, 2013).

\section{Kesimpulan}

Berdasarkan observasi beragam permasalahan yang ada di lapangan terkait dengan pengelolan data warga binaan pemasyarakatan, Direktorat Jenderal 
Pemasyarakatan dalam hal ini menggunakan system aplikasi berbasis teknologi yang dinamakan Sistem Database Pemasyarakatan (SDP). Penulis menganalisa terdapat 5 hal penting yang harus diperhatikan dalam pemanfaatan teknologi yaitu: 1. Sarana dan prasarana, 2. Sumber daya manusia. 3. Arus perkembangan teknologi. 4. Anggaran. 5. Keamanan data

Dengan pengelolaannya diatur berdasarkan Surat Edaran Optimalisasi SDP No.PAS-5.TI-01.04.159 Tahun 2013, diharapkan sumber daya manusia di lingkungan pemasyarakatan dapat melaksanakan tata tugas yang sesuai dengan aturan dan mampu melakukan pengelolaan data warga binaan dengan semestinya, sehingga diharapkan dapat menghasilkan keterbukaan informasi public yang mengutamakan unsur kerahasiaan data.

Dibutuhkan dukungan nyata dalam penyelenggaraan pengelolaan data warga binaan, yang tidak lepas dari peran teknologi dan pengembangannya, sehingga dibutuhkan bimbingan teknis bagi pelaksana pengelolaan data warga binaan pemasyarakatan secara berkala yang disesuaikan juga dengan pengembangan System Database Pemasyarakatan (SDP) sesuai kebutuhan dan untuk mewujudkan keterbukaan informasi dan dibutuhkan konsistensi petugas pemasyarakatan dalam mengikuti perkembangan teknologi sehingga memacu keinginan petugas selaku sumber daya manusia untuk berkembang sehingga mampu melakukan pengelolaan data dengan baik dan menghadirkan informasi public yang bersifat terbuka atau transparan namun mengutamakan aspek keamanan dan kerahasiaan data. 


\section{BIBLIOGRAFI}

Ahmad, Amar. (2012). Perkembangan Teknologi Komunikasi dan Kesenjangan Informasi: Akar Informasi dan Berbagai Standarnya. Jurnal Dakwah Tabligh, 13(1), 137-149.

Bangun, W. (2017). Manajemen SDM Hubungan Industrial. Jakarta: Erlangga.

Direktorat Informasi dan Komunikasi Direktorat Jenderal Pemasyarakatan. SE optimalisasi sdp 2013. , Pub. L. No. PAS-5.TI.01.04-159 (2013).

Dr. Laksmi, M., Fuad Gani, M., \& Drs. Budiantoro, M. (2018). Manajemen Perkantoran Modern. Depok: Rajawali Pers.

DR. Rasto, M. (2016). Manajemen Perkantoran Paradigma Baru. Bandung: Alfabeta

Ekonomi, G. (2020, Juli 18). Maintenance (Pemeliharaan). Retrieved from sarjanaekonomi.co.id: https://sarjanaekonomi.co.id/maintenance/

Febriyanti, Aulia, \& Hidayanto, B. C. (2012). Manajemen Risiko pada Pengelolaan Data di Bagian Pengolahan Data PT Petrokimia Gresik. Jurnal Teknik Pomits, $1(1), 1-6$.

Informasi, Direktorat, Komunikasi, D. A. N., Direktorat, S. U. B., Dan, Data, Pengembangan, Seksi, \& Database, Sistem. (2013). Standar dan modul layanan berbasis informasi teknologi direktorat jenderal pemasyarakatan.

K, V. (2016, maret). Pendekatan-pendekatan Dalam Penelitian Kualitatif. Retrieved from Academia: www.academia.edu

Komalasari, Rita. (2016). TEMATIK - Jurnal Teknologi Informasi Dan Komunikasi Vol. 3, No. 1 Juni 2016. Jurnal Teknologi Informasi Dan Komunikasi, 3(1), 86-99.

Kristiyanto, Eko Noer. (2016). Urgensi Keterbukaan Informasi dalam Penyelenggaraan Pelayanan Publik (Urgency of Disclosure of Informationin The Implementation of Public Service). Jurnal Penelitian Hukum De Jure, 16(2), 231.

Laksmi, F. Budiantoro. (2008). Manajemen Perkantoran Modern. Jakarta: Penerbit Pernaka.

Lubis, Ernayanti. (2014). Penelitian Deskriptif Kualitatif. Fakultas tarbiyah Dan keguruanuin Alauddin Makassar

Rizan Machmud. (2013). Peranan penerapan sistem informasi manajemen terhadap efektivitas kerja pagawai lembaga pemasyarakatan narkotika (lapastika) bollangi kabupaten gowa. Jurnal Capacity STIE AMKOP Makassar

Silalahi, Dhion. (2014). Perancangan Program Keamanan Data File Teks Dengan Menggunakan Algoritma Vertical Bit. Skripsi Program Studi Teknik Informatik 
Rayinda Estri Maula

STMIK Budidarma Medan

Suwardi, A. W. (2014). Penerapan Layanan Teknologi Infoemasi Dalam Pelaksanaan Penyimpanan dan Pengelolaan Benda Sitaan Negara dan Barang Rampasan Negara Di Rumah Penyimpanan Benda Sitaan dan Barang Negara Kelas I Bandung. Depok. Akademi Ilmu Pemasyarakatan

Taylor, I. (2014). Measuring Competency For Recruitment and Development. Jakarta Pusat: PPM Manejemen.

Unnamed. (2017). Unikom. Retrieved from Unikom: https://elib.unikom.ac.id/files/disk1/455/jbptunikompp-gdl-klaveryusi-22747-912.uniko-i.pdf

Violetta K. (n.d.). Pendekatan-pendekatan Dalam Penelitian Kualitatif. Retrieved from www.academia.edu 